\title{
obserwacją a wspomnieniem. Strategie poetyckie Macieja Roberta ${ }^{1}$
}

Maciej Robert, poeta, krytyk i bloger literacki, z wykształcenia filmoznawca, jest autorem pięciu tomów poetyckich. Debiutował zbiorem Pora deszczu (2003), kolejne to: Puste pola (2008), Collegium Anatomicum (2011), Księga meldunkowa (2014) i Nautilus (2016). Za Collegium... otrzymał nagrodę Polskiego Towarzystwa Wydawców Książek, wcześniej był laureatem konkursów im. Baczyńskiego, Herberta, Wojaczka, Rilkego.

Krytyczny opis wykreowanej przez niego poetyckiej wizji, niezwykle konsekwentnie realizowanej w kolejnych zbiorach, zacznę od fragmentu wiersza Śmieci z tomu drugiego, z Pustych pól:

I.

Za dwa lata nie będzie już tego domu. Taka dysproporcja w zabudowie ulicy, naniesiona przez śmierć. A ona jeszcze poprawia makijaż i pościel, którą wniosła w posagu, wynosi na parapet. Tę samą, pod którą kochali się często, aż kiedyś jej stopa rozerwała haftki, wysupłała guzik i rozdarła poszewkę - ślad został do tej pory. Za dwa lata nie będzie już niczego, w monogramie na kołdrze wyblakną litery, a jej dzieci wszystko wyrzucą na śmietnik. Cała kamienica runie nagle w dół, potem nawet mlecze zawędrują na pozostałość

" Uniwersytet Łódzki, Wydział Filologiczny, Instytut Filologii Polskiej, Katedra Literatury i Tradycji Romantyzmu, e-mail: tomcies@uni.lodz.pl.

${ }^{1}$ Niektóre rozpoznania i sformułowania zawarte w szkicu zapisałem wcześniej w drobnych notach recenzenckich trzech tomów Macieja Roberta (Collegium Anatomicum, Ksiegga meldunkowa i Nautilus), które publikowałem na łamach łódzkiego miesięcznika „Kalejdoskop” w latach 2011-2016 (Wszystkie nekrologi, „Kalejdoskop” 2011, nr 12, s. 33-34; Jeszcze ci nie mówitem, „Kalejdoskop" 2014, nr 9, s. 58-59; To miasto jest muszla, [online] http://e-kalejdoskop.pl/ to-miasto-jest-muszla.aspx (dostęp: 1.10.2016). 
dachu, a resztkami rynien popłyną strużki gruzu. I strzępki tapet trzepotać będą jak skóra na pozdzieranych kolanach szkolnej hałastry biegnącej przez podwórko. Dawniej darła się na nich $[\ldots]^{2}$

Skupmy uwage najpierw nie na tematyce, a - w zarysie - na sposobie pisania, by uchwycić główny, wyrazisty rys tych wierszy. Jeśliby próbować określić niezmienne cechy konstytutywne liryki Macieja Roberta, wynikające tyleż z rodzaju reprezentowanej przez niego wrażliwości zmysłowej, co z przyjętej świadomie strategii budowania obrazu poetyckiego, to można stwierdzić, że poezja ta jest konstruowana z nasłuchu i oglądu (czasem: podglądu). Ma stale, począwszy od debiutu, charakter narracyjny, opowiada o pojedynczych, codziennych, izolowanych zdarzeniach, rzadziej - drobnych anegdotach, rysuje obyczajowe obrazki. Jako nieprzypadkową i ciągle obowiązującą traktuję deklarację poetycką Roberta otwierającą jego pierwszy tom, inicjującą zatem całą jego drogę twórczą:

To będzie opowieść o niczym. Na pierwszy rzut oka wszystko po staremu - falista rzeźba terenu, spokój jeziora, ruchliwość jaszczurek, do której zdążyły nas już przyzwyczaić. Ramy krajobrazu są na swoim miejscu $[\ldots]^{3}$

Ta poezja to - na planie 'narracji' - królestwo banalnego drobiazgu, ulokowane w wielkomiejskim blokowisku (o rysach dość często, ale nienatrętnie łódzkich, zważywszy choćby na topografię i przywoływane nielicznie nazwy miejscowe) albo - częściej - na peryferiach, na przedmieściach, pomiędzy domeną człowieka i naturą (ten aspekt trzeba będzie później zresztą rozwinąć). Wiersze Roberta wypełnia nieskończony rejestr szczegółów. Dominuje tok enumeratywny, budowany tak świadomie i konsekwentnie, że aż czasem nużący (to przecież „opowieść o niczym”) telnika po zakamarkach, bocznych ścieżkach, wśród rdzy, kurzu, błota, pleśni, między śmieciami, szmatami, truchłem, porzuconymi przedmiotami, lokuje go w zniszczonych, zaniedbanych mieszkaniach ${ }^{5}$. Piętrzy w jednym lirycznym obrazie niezliczone - i niezhierarchizowane - elementy, jakby w niewiedzy, jakie z nich mogą się okazać ważniejsze, a które mniej ważne, jakby w obawie, że pominięcie któregoś oznaczać może uronienie czegoś naprawdę istotnego (przypomnijmy, najpierw: "To będzie opowieść o niczym.” - ale przecież i dalsze dopowiedzenie - ostrożne, a może raczej przewrotne - w drugiej części wersu: „Na pierwszy rzut oka”). Robert snuje

${ }^{2}$ M. Robert, Śmieci, [w:] tenże, Puste pola, Łódź 2008, s. 48.

${ }^{3}$ M. Robert, To będzie opowieść o niczym. Na pierwszy rzut oka..., [w:] tenże, Pora deszczu, Kraków 2003, s. 3.

${ }^{4}$ Robert Rybicki pisał odnośnie do Pustych pól o „fotograficznej dokładności szkicowania świata" oraz o jego hiperrealizmie [online] http://www.literackie.pl/artykuly.asp?idauto$\mathrm{ra}=54 \&$ idtekstu=2567\&page $=0$ \&lang $=\mathrm{PL}($ dostęp 09.05.2015).

${ }^{5}$ Ten rejestr ekspresywnych obrazów obecny jest w szczególnym natężeniu $\mathrm{w}$ dwu pierwszych tomach. 
swoje liryczne narracje to z perspektywy uczestnika i głównego bohatera, to znów - jak w przytocznym na wstępie wierszu Śmieci - jako baczny obserwator (wręcz podglądacz), obdarzony pewnym naddatkiem świadomości, którą można by nazwać „wrażliwością na przemijanie”, zmysłem wanitatywnym. Jest 'tu i teraz'; podmiot opowiada o 'teraz', a jednocześnie widzi owego 'teraz' koniec, widzi $\mathrm{w}$ istocie, że 'teraz' to konstrukcja chwiejna, chwilowa, ulegająca destrukcji, nieustannie skazana na umieranie i ciągle - także w tym swoim 'teraz', w tym 'byciu' - umierająca.

I tu dotykamy głównego tematu tej liryki. Omówienie twórczości łódzkiego poety mogłoby nosić tytuł "Maciej Robert. Wszystkie imiona śmierci” - bo o tym w istocie ona głównie mówi. Maciej Robert pisze o nieuniknionym przemijaniu: „[...] To przecież // takie ludzkie: spotkać się, pogadać; był sierpień / (rośliny w zenicie - obiektywnie mówiąc), zaraz / / potem śnieg. $[\ldots]^{\prime \prime}$, o tym, że „We wszystkim drzemie pleśń i w pleśni wszystko drzemie" , że świat to "wielkie nic" ${ }^{\prime \prime}$, że to "[...] Usypisko śmierci bez krwawych / wybroczyn.[...]" ${ }^{\prime \prime}$, a „Koniec świata zastaje mnie właśnie teraz, tutaj"10, zatem „,[...] Pamięć [jest] przymusowo / zatrudniona wymazywaniem dat, imion i rze-

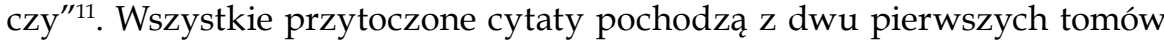
poety, bodaj najbardziej ekspresywnych i przez to jeszcze w akiejś mierze młodzieńczych. Ale i kolejne dwa, Collegium Anatomicum i Ksiega meldunkowa, podejmują ten sam temat - wszechobecnej śmierci, marności naszego 'tu i teraz'.

Pierwszy liryk zbioru trzeciego, Collegium Anatomicum - Perspektywa - to opowieść o kruchości życia, zbudowana, jak wiele wcześniejszych wierszy, jako prosty obyczajowy obrazek: ojcowie na spacerze z dziećmi; jeżdżące na łyżwach „[...] grupki gnojków wyjętych spod opieki i władzy / rozumu [...]". Ledwie zarysowana, szkicowa kreacja świata: od planu ogólnego do szczegółu. Od chwilowej rodzinnej sielanki po doświadczenie (a może tym razem tylko przeczucie?) śmierci: „Pod stopami przepełznie niejasno pęcherzyk / powietrza, jak oczko w wasserwadze). Dalej kończy się lód"12. Śmierć pojawia się nieomylnie, gdzieś z boku, jakby mimochodem. Ale następny wiersz to poetycki zapis następnego przypadku śmierci (albo raczej: przypadkowej śmierci). I kolejny, kolejny. Zatem: śmierć, nic więcej - bo to ona jest wszystkim, nic ponad nią nie istnieje, a ona istnieje we wszystkim. Uobecniona przez poetę $\mathrm{w}$ różnych dekoracjach, w różnych zajmujących mikroopowieściach, dosłowna, fizyczna - ale też bardziej metaforyczna, jakby dopiero gdzieś wisząca w powietrzu, jakby wyczekująca. Robert konstruuje, poprzez niedopowiedzenie, z drobiazgowych obserwacji i $\mathrm{w}$ rozmyciu $\mathrm{w}$ tym szczegółowo opisywanym świecie, miniaturowe zapisy śmierci, jej rozmaite wcielenia. Te liryczne szkice zdają się być wyjątkowo bliskie banalnej codzienności, drobnych wspomnień i spostrzeżeń.

\footnotetext{
${ }^{6}$ M. Robert, Kollaps, [w:] tenże, Puste pola, s. 52.

7 Tenże, Komunikat, [w:] dz. cyt., s. 55. W wierszu zapis kursywą - przyp. T.C.

${ }_{8}$ Tenże, Plener (co najmniej 2 w 1), [w:] Pora deszczu, s. 47.

${ }^{9}$ Tenże, Odptyw, [w:] dz. cyt., s. 42.

${ }^{10}$ Tenże, To samo co zwykle, tak samo jak zawsze, [w:] dz. cyt., s. 29.

${ }^{11}$ Tenże, Wariacje B-moll, [w:] dz. cyt., s. 37.

${ }^{12}$ Tenże, Perspektywa, [w:] tenże, Collegium Anatomicum, Poznań 2011, s. 5.
} 
Śmierć ludzka i zwierzęca, z głupoty, zrządzenia losu, choroby. Samotność, niespełnienie - albo nawet proste niepowodzenie - to także, $w$ tym świecie, imiona śmierci. Bo przecież ta fizyczna niczym $\mathrm{w}$ istocie nie różni się od poczucia życiowej pustki, jaka jest udziałem choćby bohaterki wyodrębnionego w tomie ośmioczłonowego cyklu wierszy Second hand, last minute ${ }^{13}$. Ten cykl należałoby zresztą uznać za sygnał istotnej zmiany poetyckiej konwencji w stosunku do tomów poprzednich: Robert, wierny w zasadzie jednemu tematowi, w Collegium Anatomicum i w Księdze meldunkowej w większym stopniu, niż czynił to wcześniej, rozpisuje go „na osoby", powołuje do poetyckiego życia rozmaitych bohaterów - i coraz bardziej rozumienie śmierci metaforyzuje oraz rozszerza. To właśnie: migotliwość i niejednoznaczność pojęcia śmierci powstrzymać nas musi przed pójściem w interpretacji bezpieczną, bo rozpoznaną po wielekroć drogą kulturowych nawiązań. Chciałoby się przecież te $-\mathrm{z}$ jednej strony niebezpiecznie uwodzące swoją urodą, z drugiej porażające - obrazy odczytać (a dzięki temu też oswoić) poprzez odniesienie do biblijnego "marność nad marnościami i wszystko marność, wypowiadanego w perspektywie wieczności. Chciałoby się, ale nie można, więcej - byłoby to nadużyciem. W poetyckiej wizji Macieja Roberta nie otwiera się perspektywa eschatologiczna (co nie oznacza, że jest wyraziście zanegowana; poetyckie narracje zatrzymują się na tym progu i poza ten próg nie zaglądają). Śmierć - a raczej Leśmianowskie 'śmiercie' - nie są $\mathrm{w}$ tomie Collegium Anatomicum ostatecznie upragnionym końcem ziemskiej wędrówki - ku zaświatom. Człowiek w poetyckiej kreacji Roberta jest w jakiejś mierze Heideggerowskim "Sein zum Tode" - istnieniem ku śmierci. Śmierć jawi się tu bowiem jako sama istota życia, jest jak ukryta sieć łącząca wszystko, co istnieje i czego doświadczamy. Jest - od zawsze i pewna. Obrazowo wyraził to Maciej Robert w wierszu Imago:

$[\ldots]$

Pamięć się rozsnuwa jak jutlandzki torf. Rdza składa tu jaja, za kilka lat wylęg podpełznie pod miasto i zarzuci żagiew w sam środek snu, zarządca bez zębów podejdzie do okna, połknie jednym haustem to zarzewie ognia, tę armię zarodników, puchnącą pod językiem w dorodne imago. Budzimy się z krzykiem. Nasze żony $\mathrm{z}$ trwogą łapią nas za ręce. Jest środek nocy $\mathrm{y}^{14}$.

Świat, mimo tkwiących w nim owych jaj rdzy, owych zarodników śmierci, mimo swojego banału i bylejakości, potrafi nadal uwodzić w wielości wcieleń, właśnie w tych drobnych anegdotach, aluzjach i obrazach, w których odnaleźć się może zapewne każdy urodzony w latach 70., a tym bardziej - urodzony wcześniej. Wróćmy do debiutanckiej Pory deszczu, by przypomnieć Filatelistykę. Wiersz pokoleniowy, utwór prowokacyjnie

\footnotetext{
${ }^{13}$ Tenże, Second hand, last minute, [w:] dz. cyt., s. 29-36.

${ }^{14}$ Tenże, Imago, [w:] dz. cyt., s. 8.
} 
i pozornie skrojony na kształt generacyjnego wyznania - manifestu wspólnoty doświadczenia. Z czego się ono, owo doświadczenie, składa? Kiedyś (wtedy, w dzieciństwie): zbieranie znaczków i akwarystyka, teraz (po latach, $\mathrm{w}$ wieku dorosłym): kolekcjonowanie straconych złudzeń, niespełnień - to jest jak oglądanie (na znaczkach) balonów Mongolfiera czy Zeppelina - „po kolei pękają, z cichym trzaskiem, ze świstem, / [...] / ulegają awarii i płoną w powietrzu, wciąż lecąc. [...]"15.

Ksiegę meldunkowa z 2014 roku należy czytać, z jednej strony, w pełnej zgodzie ze wskazanym już uobecnionym w poezji Roberta wymiarem wanitatywnym ludzkiego losu, z drugiej zaś - perspektywę tę zbiór ów bodaj przekracza. To wiersze najbardziej wyraziście w dorobku poety "łódzkie" - w tym sensie, że autor kreuje przestrzeń powłókienniczego miasta, tego obecnego i tego sprzed lat, które widziane jest - równocześnie i równolegle poprzez bieżące obserwacje i wspomnienia bohatera lirycznego. To podróże po mieście i poza nie (łódzkie Chojny i Komorniki, ulice Piesza, Społeczna, Chóralna, ale też bliżej nieokreślone przedmieścia) - 'tu i teraz'. To także odległe reminiscencje $z$ dzieciństwa, gdy grało się w piłkę, pośpiesznie okładało się zdarte kolano liściem babki, szwendało się po wertepach i nieużytkach, słuchało się muzyki z radia, czytało książkę pod kołdrą, z latarką, a wakacje spędzało się nad morzem lub na wsi. Bohater tych wierszy, którego autor obdarzył wyraźnie wieloma swoimi cechami, wieloma swoimi doświadczeniami, konsekwentnie buduje i odbudowuje ze wspomnień obrazy i sytuacje niezwykle żywe i barwne, a do tego stopnia szczegółowe, że wręcz jakoś niepokojące. Jak wcześniej, jak u początku twórczości, przygląda się każdemu szczegółowi i nasłuchuje, nadal potrafi być wyjątkowo bacznym obserwatorem. To specjalny zresztą rodzaj obserwacji. Dlaczego? Plan obcego miasta, nawet najprzejrzystszy, pozostanie do pewnego stopnia tajemnicą. Są na nim białe plamy miejsc, w których nigdy nie byliśmy i być może nigdy nie będziemy. Plan własnego miasta to zupełnie co innego. Nie ma na nim białych plam, bo przecież każdą nazwę zna się, przynajmniej ze słyszenia, z napisu na tramwaju, z notatki w gazecie - zawsze się ją jakoś kojarzy. A o wielu nazwach i zarysach ulic można powiedzieć zdecydowanie więcej, więcej nawet niż „,tu mieszkam", ,tu pracuję", , ,tu chodziłem do szkoły” - bo one właściwie określają, co dominuje w naszej pamięci, jakie miejsca oraz sytuacje znamy i jakie sobie przypominamy, zatem, do pewnego stopnia, kim jesteśmy. Kiedy patrzy się na siatkę ulic oswojonej przestrzeni, widać nie tyle ich nazwy (te są chyba najmniej istotne), co zdarzenia i twarze. I wtedy powracają emocje, nawet jeśli stłumione przez czas, to ciągle żywe. „Nasza” przestrzeń nigdy chyba nie będzie nam obojętna, to w jakimś stopniu usprawiedliwia, a może nawet czyni sensownym zanurzanie się $\mathrm{w}$ codziennym banale. Oto strategia poetycka Macieja Roberta: budować z banału, z nieefektownych drobiazgów, mozolnie nanizywanych w wierszu - by pokazać jedność 'kiedyś' i 'teraz', obserwacji i wspomnienia. Wspomnienie jest bowiem częścią codzienności, częścią 'teraz' i jako takie określa człowieka na równi z obecnymi doświadczeniami. 'Teraz' - odsyła do 'wtedy', do

${ }^{15}$ Tenże, Filatelistyka. Wiersz pokoleniowy, [w:] tenże, Pora deszczu, s. 19. 
minionego; banalny widok trzepaka na podwórku czy chłopca na rowerze przywołuje wprost doświadczenia sprzed lat. Nawet więcej: przenosi obserwatora bezpośrednio w przeszłość - i pozwala jednocześnie „byćc (teraz) tym chłopcem na rowerze, „być” (teraz) na tym trzepaku. Obie te sfery i oba czasy przenikają się, motywują i tłumaczą, stają się nierozerwalne, obie dotknięte zresztą na równi przemijaniem. Maciej Robert próbuje pochwycić, literackimi środkami, fenomeny tożsamości i pamięci w ich niepochwytnej chyba istocie. Wspominając bowiem, intensywnie, podkreślmy: melancholijnie wspominając - jesteśmy cali we wspomnieniu, w tamtym świecie, nie opuszczając jednak tego. A zwornikiem obu tych planów, areną ich konfrontacji i połączenia jest w Księdze meldunkowej niezwykle ważne miejsce: które po prostu trwa, poza czasem. Łódź - paskudna, z wyciętymi w parku drzewami, z ponurą, zdegradowaną przestrzenią, gdzie „[n]ajprostsze zachwyty” wywołują kolorowe spinacze na sznurze do bielizny na balkonie sąsiada, który „codziennie / lży matkę"16. Ale to Łódź głęboko swoja, bo przecież współokreśla, kim się jest, bo przecież wiąże się ze wspomnieniami (może lepiej napisać by: wiąże wspomnieniami?), w tym - wspomnieniem nieżyjącej babki. Jej poświęcił poeta najbardziej chyba osobiste, przejmujące, a jednocześnie jakoś w nieposkromionej potrzebie starannej obserwacji okrutne wiersze: Elegię dla Natalii Robert oraz sąsiadującą z nim Kredę. W pierwszym przywołuje obraz umierającej starej kobiety:
Odchodziła na raty, z upiornym uporem, jak rysunkowa postać, której niewidzialny autor wymazuje to rękę, to nogę, by na końcu zostawić jedynie pusty dymek, obwiedzione nic. Opuszczała to miejsce, czepiając się framug, rozsiewając się wokół - tu włosy, tam szczęka, w niedosiężnym kącie cuchnąca plama moczu. $[\ldots]^{17}$

Opis to $\mathrm{w}$ swoich drobiazgowo przedstawionych realiach przykry i przerażający - ale też jednocześnie wzniosły, wywołujący wręcz czułość, ale też będący świadectwem bezsilności. Druga część wiersza to opowieść o remoncie mieszkania po śmierci babki. Zdawać by się mogło, że to triumf trywialnego życia, trwania na przekór śmierci, bo „[...] Silikon, gładź / szpachlowa, farba emulsyjna, pięć rodzajów / pędzli, listwy, obramówki. Faktura z Castoramy". Otóż nie, „,[n]iezbywalny / zapach śmierci albo życia” trwają razem, nierozłącznie. Bo przecież śmierć, rozpad, schyłek - są niezbywalnymi składowymi wykreowanego przez autora świata. Nic tu nie opiera się śmierci. W finalnym wierszu tomu, Hojni komornicy, czytamy:

Musiało mi się pomylić. I nie ma już

ślepej uliczki, gdzie jakiś poliglota

\footnotetext{
${ }^{16}$ Tenże, Kolorowe spinacze, [w:] tenże, Księga meldunkowa, s. 30.

${ }^{17}$ Tenże, Elegia dla Natalii Robert, [w:] dz. cyt., s. 9.
} 
dopisał na znaku Dead End?

I nie ma tamtego domu, który się oparł

o cmentarz? Musiało mi się pomylić,

bo nie oparł się śmierci. I nie ma tamtej

kuchni? I nie ma poważnych rozmów?

A przecież - pamiętasz? - takie rozmowy

to jest specjalność naszej kuchni.

Przepraszam - była. Musiało mi się

pomylić. Jestem bogatszy o to,

czego mnie pozbawiono ${ }^{18}$.

Skoro tak, nie pozbawiono całkiem. Ma to w sobie, na stałe. Ksiega meldunkowa, jak wszystkie trzy poprzednie tomy, to bowiem opowieść o przemijaniu - i trwaniu, to pochwała istnienia - mimo doświadczanego wciąż nieistnienia. W drugim wierszu ostatniego tomu, Przez jakiś czas, czytamy przecież: „Martwe ciała wciąż świecą // i to się nazywa pamięć”19.

W ostatnim jak dotąd tomie, Nautilus (2016), poeta ponownie udowadnia, jak bardzo dla jego wyobraźni poetyckiej istotna jest Łódź. Ale tym razem w zdecydowanie mniejszym stopniu chodzi o konkretną topografię miasta, o jego kształt i wygląd. Łódź w Nautilusie nie jest już głównie fascynującą przestrzenią, którą warto przemierzać i obserwować. Staje się stanem ducha, jakimś trudno pochwytnym, niematerialnym fenomenem, w którym uczestniczą jego mieszkańcy. Poeta sięgnął w Nautilusie po dwie metafory ciekawie obrazowo określające, czym jest miasto. Muszla i mapa - to kluczowe pojęcia tego tomu. Łódź jest właśnie taką muszlą, „skorupą obraną z mięsa", którą wypełniają fakty, emocje i wspomnienia bohatera tomu (a może też każdego z nas z osobna?). Nie o wydarzenia historyczne chodzi, ani o miejskie mity, lecz o codzienne zdarzenia. Miasto jest dla nich swego rodzaju ramą i ochroną, ale też, z drugiej strony, ich ograniczeniem i więzieniem. Określa zatem w jakimś stopniu ich kształt i charakter, czyniąc niepowtarzalnymi, lecz jednocześnie kierunkując je i determinując. Nie da się spod tej skorupy (spiralnej, jak podkreśla kilkakrotnie poeta, więc jednocześnie labiryntowej) wyjść, bo ludzie są w zasadzie jej integralną, nieodłączną częścią. Owszem, można próbować wyznaczać wewnątrz niej jakieś własne trasy czy rysować mapy, ale to niewiele więcej niż bazgranie, stawianie znaczków, robienie notatek - na już wcześniej istniejącej, zetlałej, przetartej na krawędziach mapie miasta. Właśnie - mapie, nie planie. Miasto w poetyckiej wizji Macieja Roberta zagarnia bowiem cała przestrzeń, jest wszystkim; na jego granicy, na rozlanych, nieczytelnych przedmieściach mapa się kończy. Co stanowi o jego istocie? Własne, jednostkowe doświadczenia ludzi, wypełniające ową muszlę, skorupę i przez nią ograniczane. Podmiot liryczny wierszy Roberta wielokrotnie zapisuje drobne zdarzenia i widziane miejsca, jak działo się to $\mathrm{w}$ poprzednich tomach, ale nie są one ważne dla samych siebie, lecz jako nośniki pamięci,

${ }^{18}$ Tenże, Hojni komornicy, [w:] dz. cyt., s. 52.

19 Tenże, Przez jakiś czas, [w:] dz. cyt., s. 7. 
jako znaczniki w nieciągłej łódzkiej przestrzeni. Jak notatki na mapie, pozwalające zachować ślad tego, co nieustannie mija, ale trwa nadal w świadomości, w pamięci. Pamięć - to trzeci klucz do tego tomu. „Pamiętam, pamiętam, pamiętam" powtarza bohater, przywołując zdarzenia drobne, ale mimo to ze swojej perspektywy istotne (choć często trudno powiedzieć, dlaczego właśnie te). Pamiętanie nie jest jednak narzędziem do budowania wspomnień, a tym bardziej do barwnych anegdot czy snucia zajmujących (głównie w perspektywie autobiograficznej) opowieści o własnej przeszłości. Zapamiętane migawkowo zdarzenia zakotwiczają bohatera $\mathrm{w}$ przestrzeni miasta, a jednocześnie każą się zastanowić, na ile one same możliwe były dzięki niej, na ile wyniknęły właśnie z niej. Na ile to, co najintymniejsze, jest jednocześnie częścią fenomenu Łodzi? W tym wymiarze Nautilus nie jest zapisem doświadczenia melancholijnego, jak były nim wcześniejsze tomy Roberta. Pamięć nie oznacza tu rozpamiętywania, nie jest stanem poczucia straty. Ona w najnaturalniejszy sposób znaczy przestrzeń i oznacza w niej jednostki. Ma też jeszcze jedną funkcję do spełnienia. To bowiem poeta jest tym, który pamięta (mówi: „Miasto was nie pomieści, jestem pamięcią // zewnętrzną, ruchomą poczekalnią."). Poezja wyrasta więc z pamiętania, jest zapisem pamięci - nie ku politycznej przestrodze, nie w imię etycznych powinności, lecz z samej swojej istoty. Można to uznać za swoistą deklaracje programu poetyckiego Macieja Roberta, której nie sformułował wyraziście wcześniej. Deklarację tym ważniejszą, że tom Nautilus zdaje się otwierać nowy rozdział na jego twórczej drodze. W oszczędnych obrazowo dwuwersach, w różnej długości wierszach bez tytułu, kolejno numerowanych, które można czytać pojedynczo, ale najwyraźniej układają się w spójny poemat, Maciej Robert porzuca tak charakterystyczną dla swoich wcześniejszych tomów fotograficzną wrażliwość, porzuca krok flanêura, nieśpiesznego wędrowca przemierzającego miasto, by zejść głębiej, by zanurzyć się w labiryncie. Nadal arcyłódzki, skupia się na doświadczeniu uniwersalnym: stawia pytanie o to, na ile i jak człowiek jest częścią przestrzeni, w której żyje - i na ile ona jest częścią jego samego.

Wróćmy jeszcze raz $\mathrm{w}$ podsumowaniu do poetyckiej strategii i poetyckich filiacji liryki Macieja Roberta, filiacji ważnych zwłaszcza u początków jego drogi twórczej. Wrażenie przenikania się 'tu' i 'teraz' 'tu' i 'wtedy', z 'tam' i 'wtedy' wzmaga nie tylko chwyt pieczołowitej, aż po znużenie, enumeracji, w obrębie której zacierają się granice teraźniejszości i przeszłości, doświadczenia i wspomnienia. Człowiek jest w jego poezji w równym stopniu bytem społecznym, co przynależy do natury, jest jak najdosłowniej pomiędzy - miastem a naturą (łąką, brzegiem stawu czy rzeki), pomiędzy zamkniętą przestrzenią domu (mieszkania w bloku czy starej kamienicy) a tym, co na zewnątrz, co nieogarnione, lecz wspól-istotne, tożsame w istocie, bo tożsame w śmierci. Dzieje się to w równej mierze na poziomie samej poetyki: Robert konsekwentnie, zwłaszcza w debiutanckiej Porze deszczu, przydaje pojęciom ze sfery natury epitety czy atrybuty ludzkie - i odwrotnie (,bandaż kory”, "liść trzciny podłużny niczym ostrze kuchennego noża”, „łabędzie fastrygują matariał nieba”, a z drugiej strony: „trzepot jarzeniówek”, 
"gasnący puls freonu”, „różaniec kurzu”, „nielegalne kłęby kurzu”, ,arkusz gładkiej skóry” [w erotyku!], „zakneblowane niebo"20).

Sposoby odczytania poezji Roberta kierunkuje też zastosowany przez niego, w obrębie poszczególnych tomów, zabieg, który wyprowadzać by należało z techniki motażu filmowego. Wiele równoległych ujęć i planów, wiele epizodów, pozornie zupełnie niezależnych, które, jak we współczesnym kryminale, porządkuje trudno pochwytna nić „intrygi”, temat główny: śmierć, nic więcej.

I jeszcze jedno, na koniec. W krytyce literackiej podejmującej się próby opisu poezji roczników 60. ważne (i modne) było poszukiwanie pomiędzy poszczególnymi twórcami związków i inspiracji. Jak - jeśli w ogóle - „mapować" lirykę Macieja Roberta? Poeta nie buduje wyraźnych związków intertekstualnych. W pierwszym tomie dostrzec można powierzchowną grę z wierszami uznanych poetów - poprzez nadanie kilku lirykom ich tytułów (Miłosza Piosenka o końcu świata; Świetlickiego Zimne kraje) czy aluzyjne odniesienie do wiersza Klejnockiego Spügen, stacja benzynowa w utworze Zachód słońca nad stacją benzynowa. Maciej Robert wyrósł ${ }^{21}$ chyba (trudno mówić o tym z pełnym przekonaniem; to zaledwie intuicja, w zasadzie nieweryfikowalna, bo świadectw poetyckich filiacji, choć licznych, nie można zaklasyfikować jednoznacznie w obrębie nowej liryki jako specyficznie "czyichś") z lektur trzech ważnych współczesnych sobie twórców: Romana Honeta (o czym decyduje somatyczna ekspresywność obrazowania i metaforyki, do fascynacji poezją autora Alicji Robert przyznaje się zresztą wprost), Tomasza Różyckiego (melancholijność, predylekcja do bocznych ścieżek, chaszczy i peryferii) oraz Krzysztofa Siwczyka (zwłaszcza z jego debiutanckiego tomu Dzikie dzieci - ze względu na specyficzne sfunkcjonalizowanie wspomnień z dzieciństwa). To jednak wyraźnie poezja osobna i dojrzała.

\section{B I B LIOGRA F I A}

Małochleb P., Metafizyka i gładź szpachlowa (Maciej Robert, "Księga meldunko$\left.w a^{\prime \prime}\right)$ [online] http://krytykanaostro.blogspot.com/2014/08/metafizyka-i-gadz-szpachlowa.html (dostęp: 1.10.2016).

Rybicki R., [online] http://www.literackie.pl/artykuly.asp?idautora=54\&idtekstu=2567 \&page=0\&lang=PL (dostęp: 1.10.2016).

Skurtys J., Kim jesteś, Nemo? (Maciej Robert, "Nautilus”), ArtPAPIER 2016, nr 15-16, (303-304) [online ]http://artpapier.com/index.php?page=artyku$1 \& w y d a n i e=306 \& a r t y k u l=5679$ (dostęp: 1.10 .2016$)$.

${ }^{20}$ Zob.: tenże, Pora deszczu, s. 3, 14, 22, 30.

${ }^{21}$ Zresztą chyba dosłownie „wyrósł”, bo coraz bardziej odnajduje swoją, osobną dykcję, o czym przekonująco pisze, analizując Nautilusa, Jakub Skurtys, Kim jesteś, Nemo? (Maciej Robert, "Nautilus"), ArtPAPIER 2016, nr 15-16, (303-304), [online] http://artpapier.com/index. php?page=artykul\&wydanie=306\&artykul=5679 (dostęp: 1.10 .2016$)$. 
Macieja Roberta pytamy o "Nautilusa”. „Najmocniej zżyci jesteśmy z tym, co napisaliśmy ostatnio.", Z Maciejem Robertem rozmawia Roman Honet [online] http://www.literackapolska.pl/kilka-pytan-do/macieja-roberta-pytamy-o-nautilusa/ (dostęp: 1.10.2016).

\section{STRESZCZENIE}

Artykuł jest próbą interpretacji dotychczasowego dorobku łódzkiego poety Macieja Roberta. Opisuje najważniejsze składowe dykcji poety, specyfikę jego obrazowania oraz główne obszary tematyczne obecne w tej liryce. Przedmiotem refleksji są także zmiany zachodzące w twórczości Macieja Roberta oraz ważne dla niego inspiracje, czerpane między innymi od Tomasza Różyckiego i Krzysztofa Siwczyka.

\section{Słowa kluczowe}

liryka polska XXI wieku, Maciej Robert, Łódź

\section{S U M M A RY}

\section{Between reflection and reminescence. Maciej Robert's poetic strategies}

The article is an attempt to interpret Maciej Robert's poetic output to date. It provides a description of the poet's most crucial means of expression, his unique manner of imagining and the main thematic areas which are present in his poems. Another subject of reflection the articles focuses on are also the transformations his poetry undergoes and the significant inspirations he draws from such authors as Tomasz Różycki and Krzysztof Siwczyk.

\section{Keywords}

Polish $21^{\text {st }}$ century lyrics, Maciej Robert, Lodz 